\title{
The Hydric Environment: A Hub for Clinically Relevant Carbapenemase Encoding Genes
}

\author{
Florence Hammer-Dedet ${ }^{1}$, Estelle Jumas-Bilak ${ }^{1,2}$ and Patricia Licznar-Fajardo ${ }^{1,2, *}$ \\ 1 UMR 5569 HydroSciences Montpellier, Université de Montpellier, CNRS, IRD, 34090 Montpellier, France; \\ florence.hammer-dedet@umontpellier.fr (F.H.-D.); estelle.bilak@umontpellier.fr (E.J.-B.) \\ 2 Département d'Hygiène Hospitalière, CHU Montpellier, 34090 Montpellier, France \\ * Correspondence: patricia.licznar-fajardo@umontpellier.fr
}

Received: 14 September 2020; Accepted: 10 October 2020; Published: 15 October 2020

\begin{abstract}
Carbapenems are $\beta$-lactams antimicrobials presenting a broad activity spectrum and are considered as last-resort antibiotic. Since the 2000s, carbapenemase producing Enterobacterales (CPE) have emerged and are been quickly globally spreading. The global dissemination of carbapenemase encoding genes (CEG) within clinical relevant bacteria is attributed in part to its location onto mobile genetic elements. During the last decade, carbapenemase producing bacteria have been isolated from non-human sources including the aquatic environment. Aquatic ecosystems are particularly impacted by anthropic activities, which conduce to a bidirectional exchange between aquatic environments and human beings and therefore the aquatic environment may constitute a hub for CPE and CEG. More recently, the isolation of autochtonous aquatic bacteria carrying acquired CEG have been reported and suggest that CEG exchange by horizontal gene transfer occurred between allochtonous and autochtonous bacteria. Hence, aquatic environment plays a central role in persistence, dissemination and emergence of CEG both within environmental ecosystem and human beings, and deserves to be studied with particular attention.
\end{abstract}

Keywords: carbapenemase; aquatic environment; one-health; horizontal gene transfer

\section{The Carbapenem Resistance Issue: The Importance to Mesh the Aquatic Environment}

Antimicrobials are obviously one of the most significant discovery of the past century. Their use has allowed important advances in preventing or delaying the onset of bacterial infections in medicine and veterinary practices, and have also been largely used as prophylactic and growth promoter agents in animal husbandry and farming. However sometimes, acquisition of antimicrobial resistance (AMR) determinants by bacteria occurs, either by selection of resistant bacterial mutant or by horizontal transfer of AMR determinant-encoding genes within bacterial species [1]. Due to the overuse and the misuse of antimicrobials, a selective pressure places to bacteria enhancing dramatically AMR that results in failures of antimicrobial treatment efficacy. By far, $\beta$-lactams are the most consumed antibiotic worldwide [2]. This class of antibiotic includes penicillins, cephalosporins, monobactams and carbapenems. Carbapenems, such as imipenem or meropenem, present the broadest spectrum of activity and a bactericidal activity against many Gram-negative and Gram-positive bacteria [3,4]. Their particular chemical structure confers protection against most of the $\beta$-lactamases produced by bacteria including cephalosporinases or extended-spectrum $\beta$-lactamases (ESBL) $[4,5]$. Consequently, carbapenems are considered as last-resort antibiotics and are used to treat bacterial infections when all other therapeutic options fail [5]. Therefore, bacterial carbapenem resistance is an important public health concern. Among carbapenem-resistance determinants, carbapenemase enzymes are the most relevant clinically and the most worrying because; (i) these enzymes hydrolyse almost all $\beta$-lactams, including carbapenems that limit severely therapeutics options; and (ii) clinically relevant 
carbapenemases are encoded by genes located onto genetic mobile elements, such as transposons or plasmids and are horizontally transferable within different bacterial species. This is particularly true for Gram-negative bacteria, especially for Carbapenemases Producing Enterobacterales (CPE) that have emerged in the 2000s, have quickly globally spread, and are associated with health-care associated infection and important mortality rate $[6,7]$.

In the last decade, clinically relevant CPE have been isolated from non-human sources, including animals, food chain and the environment [8], highlighting the necessity to consider human, animal and environmental interfaces for the struggle against AMR under the holistic approach named the «One-Health» concept [1,9]. Among components of the «One-Health» triad, the environment and more particularly the aquatic environment represents a crucial component as it is strongly linked with anthropic activities. These activities lead to multiple selection pressures exerted on the bacterial community [1,10], as well as meetings and exchanges between human and environmental bacteria. Urban aquatic environments are particularly impacted by anthropic activities, such as the discharge of habitations, urban runoffs, and hospital sewages [11-15], wastewater treatment plants (WWTP) effluents [13,16,17] and domestic or recreational activities [13,18]. While, urbanization of human habitats is on the rise, rural hydric environments are also impacted by animal husbandry and farming activities [19]. Then, humans could be exposed to Carbapenemase Producing Bacteria (CPB) including $\mathrm{CPE}$, contained in aquatic environment, either directly during recreational activities, after flood episodes, or simply by drinking tap water [20-22], and either indirectly by foodborne transmission (re-use of treated wastewater for agricultural and livestock activities) [23,24]. Therefore, mixes between aquatic environmental communities and bacterial communities from human beings are consequently bidirectional and aquatic ecosystems constitute a hub for CPB. Moreover, these aquatic environments could act as reservoir for clinically relevant CPB, but also for Carbapenemase Encoding Genes (CEG). Since it contains diverse autochtonous bacteria which could exchange genetic material by Horizontal Gene Transfer (HGT) with allochtonous bacteria (e.g., CPE from human or animal microbiota) and vice versa, aquatic environment plays a central role in persistence, dissemination and emergence of CEG both, within environmental ecosystem and human beings and deserves to be studied with particular attention.

This paper therefore seeks to provide justification for considering potential roles of aquatic autochtonous bacteria in the emergence, the dissemination and the persistence of CEG and the requirement to study $\mathrm{CPB}$ in aquatic ecosystem for the survey and the prevention of AMR.

\section{Carbapenemases: A Clinical Success Story}

Carbapenems are hydrolysed by some specific $\beta$-lactamases called carbapenemases. $\beta$-lactamases are shelved by different classifications. The Ambler classification [25], based on the primary structure of the enzymes, is the most popular and describes four classes of $\beta$-lactamases. Only three of them, A, B and D, contain clinically relevant carbapenemases and are described below. Class C enzymes are not considered as carbapenemases as they harbour a low hydrolysis potential of carbapenems [26].

\subsection{Class $A$}

Class A carbapenemases are serine proteases which hydrolyse with greater or lesser degree penicillins, monobactams, cephalosporins and carbapenems and are partially inhibited by $\beta$-lactamase inhibitors (e.g., clavulanic acid, sulbactam, tazobactam) [5]. Some of enzymes of this class are chromosomally encoded, not transferable and confer an inherent resistance to carbapenems to bacteria species that carry them. As example, one can list SME (Serratia marcescens enzyme) and SFC-1 (Serratia fonticola carbapenemase A) for Serratia spp., or NmcA (not metalloenzyme carbapenemase A) or IMI-1/IMI-2 (imipenem-hydrolysing $\beta$-lactamase) for Enterobacter spp. Other class A carbapenemases are plasmid-encoded like KPC (Klebsiella pneumoniae carbapenemase), IMI (IMI-1 to IMI-3) or derivatives of GES (Guiana extended spectrum) [5]. 
Among these class A-enzymes, KPC is the most worrisome because of its current widespread within clinical Enterobacterales [5,27,28]. KPC enzyme was described for the first time in a Klebsiella pneumoniae isolate in United States in 1996. This discovery was quickly followed in 2001 by the description of a novel single amino-acid variant KPC-2 [29] which became global in less than ten years [30]. It is worth noting that recent resequencing of $b l a_{\mathrm{KPC}-1}$ revealed that it was identical to $b l a_{\mathrm{KPC}-2}$ and thus KPC-1 and KPC-2 variants are identical too [31]. Since then, more than 44 KPC variants have been described but do not harbour the same ability to hydrolyse carbapenems. For instance, some of them such as KPC-31, KPC-33, KPC-14 or KPC-28 are not considered as carbapenemase enzymes [30] while KPC-2 and KPC-3 present a broad spectrum of hydrolysis of $\beta$-lactams and are from the most frequent variants encountered in clinically strains [32].

The global success of the KPC-2 spread within clinical Enterobacterales could be owed to; (i) its frequent association with the nosocomial successful K. pneumoniae sequence type (ST) 258 [33-35]; and (ii) the particular genetic context of its encoding gene (Figure 1). Indeed, bla $a_{\mathrm{KPC}-2}$ is located on Tn4401, a Tn3-type transposon which possesses a resolvase $(\operatorname{tnpR})$, a transposase $(\operatorname{tnp} A)$ and two insertion sequences ISKpn6 and ISKpn7. Different variants of Tn4401 carrying different internal deletions have been identified. A nomenclature with lowercase letter is employed to distinguish these variants. The most common form is Tn4401a which gives the highest level of carbapenem resistance [36]. Tn4401 exhibits a high transposition frequency and allows the dissemination of $b l a_{\mathrm{KPC}-2}$ gene within a large range of plasmids and bacterial species $[37,38]$. Therefore, it is also encountered in bacteria isolated from hydric environments.

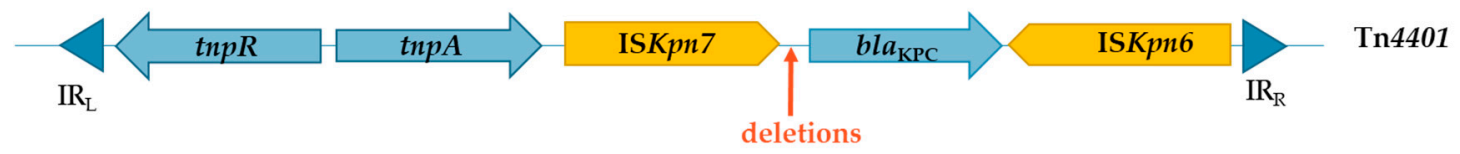

Figure 1. Diagram of Tn4401 structure, according to Nordmann et al., 2011 [32] and Partridge et al., 2018 [36]. Genes and their corresponding transcription orientation are indicated by large blue arrows. The Tn4401 is delimited by two inverted repeat (IR) sequences, represented by dark blue triangles. Tn4401 carries $b l a_{\mathrm{KPC}}$ gene, it is a Tn3-type transposon which possess a resolvase and a transposase respectively encoded by $t n p R$ and $t n p A$ and two insertion sequences (yellow large arrows) ISKpn6 and ISKpn7. Approximative position of deletions leading to different variants of $\mathrm{Tn} 4401$ are represented by the thin orange arrow.

For instance, Mathys and colleagues have isolated different bacterial species which carry $b l a_{\mathrm{KPC}}$ genes on different classes of plasmids from WWTP effluents [23]. In their study, Sekizuka et al. identified similar IncP-6 plasmids carrying bla $\mathrm{KPC}_{2}$ genes in Klebsiella sp., Citrobacter sp., Enterobacter sp., Escherichia coli, Pseudomonas sp., Aeromonas caviae and Aeromonas hydrophila from WWTP effluent [39]. A Chinese study identified an IncP-6 plasmid carrying bla $a_{\mathrm{KPC}-2}$ gene in three isolates of Aeromonas taiwanensis isolated from sediments of an urban river. Interestingly the $b l a_{\mathrm{KPC}-2}$ gene was inserted in a Tn3 transposon as previously reported in clinical Enterobacterales in China and in France [40]. bla $a_{\mathrm{KPC}}$ genes have also be found to be carried by a conjugative plasmid in a K. pneumoniae strain isolated from urban lake water [41] and in Citrobacter freundii and $A$. caviae strains isolated from an urban river close to a WWTP [42].

\subsection{Class B}

Carbapenemases belonging to Ambler's class B are metallo-enzymes (also called "metallo- $\beta$ lactamases" MBL). Its active site includes at least one zinc ion $\mathrm{Zn}(+\mathrm{II})$. Most of these enzymes present a broad lysis spectrum for $\beta$-lactams. Their activity is not inhibited by the commercially available $\beta$-lactamases inhibitors but they are susceptible to ethylenediaminetetraacetic acid (EDTA), a chelator of divalent cations $[5,43]$. 
Until the early 1990s, MBLs described and studied were exclusively chromosomally encoded, conferring a species-specific resistance to carbapenems. These enzymes are widespread in environmental bacterial species such as L1 and L2 enzymes in Stenotrophomonas maltophilia, CphA in Aeromonas spp. (A. hydrophila, Aeromonas sobria, Aeromonas salmonicida) or $\beta$-lactamase II in Bacillus cereus [44-47]. Since then, a wide variety of genetic mobile element structures carrying MBL-encoding genes were identified. The most common embrace Verona Integron-encoded Metallo- $\beta$-lactamase (VIM), Imipenem-resistant Pseudomonas (IMP), Seoul Imipenemase (SIM), German Imipenemase (GIM) and the successful New Delhi Metallo- $\beta$-lactamase 1 (NDM-1).

The NDM-1 enzyme is an MBL which presents a broad lysis spectrum, hydrolysing all $\beta$-lactams except aztreonam. It was identified for the first time in 2009 in India, in a carbapenem-resistant K. pneumoniae. This strain was involved in a urinary tract infection of a Swedish patient travelled in New Delhi. The $b l a_{\mathrm{NDM}-1}$ gene has also been identified in an E. coli strain isolated from faeces of this patient. These $b l a_{\mathrm{NDM}-1}$ genes were on different transferable plasmids [48]. Since then, spreading of $b l a_{\mathrm{NDM}-1}$ gene has occurred within clinically relevant bacteria in particular in Enterobacterales, Acinetobacter spp. and Pseudomonas spp. [49-52] and until now 29 variants of NDM-1, varying by few amino-acid residues at different positions have been described [53]. Several plasmids types harbouring $b l a_{\mathrm{NDM}-1}$ gene have been identified suggesting that plasmids play a major role in the rapid dissemination of this gene to the global scale [49-55]. Among bla $a_{\mathrm{NDM}-1}$ carrying-plasmids, IncA/C plasmid type, a Broad Host Range (BHR) plasmid, generally conjugative, is frequently described $[51,53,56,57]$. This argues the involvement of this plasmid in $b l a_{\mathrm{NDM}-1}$-dissemination among different bacterial species. Some narrow-host-range plasmid are also involved in NDM dissemination. For instance, IncX3-type plasmid that is restricted to Enterobacterales, has been found in association with $b l a_{\mathrm{NDM}-5}$ gene in several clinical isolates in China $[57,58]$, including ones with the same genetic environment that an IncX3-type plasmid circulating in India and in Japan [58]. This suggests that IncX3-type plasmids may play a role in the spread of $b l a_{\mathrm{NDM}}$ (at least $b l a_{\mathrm{NDM}-5}$ ) genes within Enterobacterales. Less frequently, chromosomic bla $a_{\mathrm{NDM}-1}$ gene was identified, associated with different transposons particularly in Pseudomonas spp. and Acinetobacter spp. [59,60]. In addition of plasmids and transposons, insertion sequences (IS) may have participated to the spread of $b l a_{\mathrm{NDM}-1}$ gene too. The association of $b l a_{\text {NDM-1 }}$ with at least a remnant of ISAba125 in several bacterial species in particular Enterobacterales and Acinetobacter spp. has been noted [53,54,60,61]. In contrast, even if integrons are mobile genetic elements massively involved in AMR dissemination, integrons do not seem to be linked with $b l a_{\mathrm{NDM}}$ dissemination. A study evaluating the genetic context of clinical NDM-producing Enterobacterales strains has shown no relation between $b l a_{\mathrm{NDM}}$ gene and class 1 integron occurrences [54]. Therefore, NDM-1 encoding gene is not associated with a particular plasmid type or genetic mobile element and the genetic context of $b l a_{\mathrm{NDM}-1}$ gene is inconstant [62].

While, clinical bacteria producing NDM enzyme are broadly described, only few studies reported the isolation of NDM producers in aquatic environment. $b l a_{\mathrm{NDM}}$ genes have already been identified in Aeromonas spp., Acinetobacter spp. and Citrobacter spp. from hospital sewage effluent $[11,12]$ and different Enterobacterales species producing NDM-1, NDM-5 and NDM-7 enzymes were isolated from WWTP effluent [23]. Recently, two isolates of E. coli carrying bla $a_{\mathrm{NDM}-5}$ gene onto IncX3-type plasmids were isolated from an urban river in the South of France [63].

\subsection{Class $D$}

Class $D \beta$-lactamases are serine protease enzymes which hydrolyse preferentially oxacillin rather than benzylpenicillin, hence their usual name is OXA enzymes [64]. These enzymes are generally poorly inhibited by EDTA and penicillinase inhibitors (i.e., clavulanic acid, sulbactam, tazobactam), but their action is suppressed by avibactam $[43,65]$. As amino-acid sequences of these enzymes are variable, hydrolysis spectrum is also variable and some of them are able to hydrolyse carbapenems. They are named carbapenem-hydrolysing class $\mathrm{D} \beta$-lactamases (CHDB). CHDB enzymes were identified primary from non-fermenter organisms, such as Acinetobacter baumannii: OXA-24, OXA-25, OXA-26, OXA-27, 
OXA-40 and OXA-23 (firstly named ARI for Acinetobacter Resistant Imipenem) [64,66]. Ten years after the identification of the first CHDB [67], a novel one, the OXA-48 exhibiting a high level of resistance to all $\beta$-lactams, including carbapenems was identified from a multidrug-resistant K. pneumoniae isolate responsible of an urinary tract infection in a patient hospitalized in Istanbul [66]. The OXA-48 enzyme was weakly related to other oxacillinases, including CHDB, with a maximum of $46 \%$ of amino-acid identity. It has been shown that OXA-48 hydrolyses carbapenems at a higher level of efficiency than others CHDB previously described. Hydrolysis efficiency of OXA-48 was comparable to that of KPC enzymes [66]. Like other CHBD, OXA-48's activity is not affected by EDTA and by penicillinase inhibitors but is characterized by a sensitivity to $\mathrm{NaCl}$ conferred by the mutation Y144F [66,68]. Since then, several variants of OXA-48 enzymes, also named OXA-48 like enzymes, have been described in Enterobacterales isolates, OXA-181, OXA-232, OXA-244, OXA-204 and OXA-162 being the most common ones [69]. Unlike most oxacillinase-encoding genes described previously, the $b l a_{\text {OXA-48 }}$ gene was not part of a class 1 integron but was a plasmid-borne gene [66]. For a long time, bla $a_{\mathrm{OXA}-48}$ gene (and its variants) have been identified only in Enterobacterales [70] and its dissemination was exclusively associated with a single pOXA-48a plasmid. Complete sequencing of pOXA-48a plasmid highlighted that it was a $62.3 \mathrm{~kb}$ IncL/M-type plasmid and bla $\mathrm{OXA}-48$ was located within the transposon Tn1999 [71]. IncL/M-type plasmids are BHR plasmids, commonly identified in Enterobacterales and associated with a variety of Antimicrobial Resistance Gene (ARG) [72]. Tn1999 is a composite transposon, formed by two identical IS1999 [73] and the bla OXA-48 gene. bla $a_{\text {OXA-48 gene }}$ is located downstream one of the IS1999 which provides a promoter sequence responsible of its expression [66]. Since then, lots of studies have reported OXA-48-producing Enterobacterales (mostly Klebsiella sp.) in many countries. OXA-48 is actually the most prevalent carbapenemase in Middle East, North of Africa and Europe [69,70]. The pOXA-48 like plasmids are still considered the main source of bla $a_{\text {OXA-48 }}$ dissemination within clinical Enterobacterales [74] and in different ecological niches including urban hydric environments $[8,75,76]$. Interestingly, some studies reported the occurrence

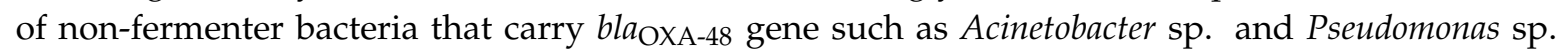
from potable tap water in US or Aeromonas sp. and S. maltophilia from biofilms of hospital effluent. Unfortunately, the genetic background of these genes have not been studied yet [11,77].

\section{Presence of CPB in Aquatic Environments: A Simply Remnant of Human Activities or an History a Little Bit More Complex Than That?}

\subsection{Emergence of CPE in Aquatic Environments: As a Consequence of Anthropic Activities}

A number of studies reported the isolation of CPE from urban aquatic environments such as surface water nearby WWTP [23], rivers [13,42,63,78-83], lakes [15,18,41] or coastal water [15,18]. In most of cases, the origin of CPE is recognized or strongly suggested to come from anthropic contaminations. The isolation of CPE such as Enterobacter sp. [78], Klebsiella sp. [13] and E. coli [63] carrying acquired CEG has been noted from urban river water considered to be impacted by anthropic activities.

Discharging habitation sewage and WWTP effluent are probably two of the main reasons for the presence of CPE in urban rivers. A study reports the isolation of Klebsiella spp. carrying $b l a_{\mathrm{KPC}-2}$ gene from river water samples and also shows a deterioration of the water quality along the river downstream of the dwellings [13]. Previous studies have reported the occurrence of CPE in WWTP effluent and in aquatic environment nearby WWTP (or in which WWTP effluent are discharged) $[17,23,42]$. Hospital sewage wastewaters are also a source of contamination for urban aquatic environment. Hospital sewage is considered a hotspot for HGT of ARG since its contains multi-resistant bacteria, viruses [84], antibiotics and biocides [14]. CPE is also commonly present in hospital sewage wastewater [85]. As an example, K. pneumoniae belonging to high-risk hospital associated lineage (CC11, CC258) carrying plasmidic bla $a_{\mathrm{KPC}-2}$ gene has been reported in urban aquatic areas close to hospital settings [41,82].

While, the most likely reason for the occurrence of CPE in urban water is an anthropic contamination, it is also possible that aquatic environment contains persistently CPE, which can 
act as a reservoir and could play the role of a source for acquisition of CEG by other bacteria through HGT, and for future human colonization.

\subsection{Providing Persistence and Dissemination of CEG in Aquatic Environments: As an Opportunity for CPE}

In a significant way, some of Enterobacterales commonly associated with aquatic environment could constitute a reservoir for CEG in water. This is the case for species belonging to the genus Enterobacter, which are commonly found in the environment and are associated with various habitats, such as water, soil, animals and plants [86,87]. Enterobacter species are occasionally pathogens for human and are involved in nosocomial infection (especially in immunocompromised patients). Several studies have reported clinical isolates carrying carbapenemase encoding genes like $b l a_{\mathrm{IMI}}, b l a_{\mathrm{NDM}}, b l a_{\mathrm{OXA}-48}$, $b l a_{\mathrm{VIM}}$ or $b l a_{\mathrm{KPC}}$ [86-89]. Beside these clinical reports, the occurrence of carbapenemase-producing Enterobacter spp. has been notified in urban aquatic environment such as WWTP effluent, surface water, coastal water, hospital effluent and rivers [12,13,15,16,18,23,78,88,90,91]. Interestingly, some studies emphasize the persistence of Enterobacter spp. carbapenemase-encoding strains in rivers which allows to evoke its potential role as reservoir for CEG in aquatic ecosystems. Aubron et al. mentioned the presence of Enterobacter cloacae isolates clonally related and carrying $b l a_{\mathrm{IMI}-2}$ gene on a plasmid from four distantly related rivers in United States [78]. The persistence of a clonal complex of KPC-2 carbapenemase-producing Enterobacter asburiae along an urban Brazilian river was also reported [13].

Persistence of CPE in aquatic environment and their potential transmission to human is worrying and the case of an infection after a near-drowning caused by a persistent strain of IMI-2 carbapenemase-producing E. asburiae in a river of the South of France has already been reported [88].

Other Enterobacterales could play the role of environmental reservoir of resistance genes, particularly when presenting an aquatic habitat and when some strains isolated from water are known to carry carbapenemase encoding genes $[12,15,16,18,23,42,92]$. It is quite likely that CPE, regardless their origin, may play a crucial role in the persistence and the dissemination of CEG through aquatic environment to the human being. Limiting these roles to only CPE is probably an error since several studies reported the occurrence of carbapenemase-producing autochtonous bacteria not belonging to Enterobacterales order in diverse aquatic environments [11-13,15,16,18,23,39,42,77,91,93-95]. This should give us the opportunity to consider potential roles played by aquatic autochtonous CPB in the emergence, the dissemination and the persistence of CEG.

\subsection{Carbapenemase-Producing Environmental Bacteria: The Chicken or the Egg?}

Well before their discovery and their use by humans, antimicrobials were already naturally synthesized in the Environment. In fact, microorganisms are in competition for the access to nutrient and oxygen and many of them produce molecules, in order to control competitor development. For example, thienamycin (i.e., the first carbapenem molecule identified) is constitutively produced by Streptomyces cattleya, a soil environmental bacteria [96]. To protect themselves against molecules that they produce, microorganisms synthesize resistance determinants, encoded by genes generally located onto the chromosome and transmitted to progeny (i.e., vertical transmission). However, microorganisms which not produce antimicrobials can also present constitutively ARG and/or acquire de novo new ones by HGT. Therefore, it might be speculated that some CEG (like others ARG) have been mobilized from environmental bacteria and that, in a manner of speaking, environmental autochtonous bacteria could be «the egg» at the origin of CEG. Supporting this idea, it is well accepted in the scientific community that Shewanella sp., a waterborne bacterial genus, is at the origin of $b_{\text {OXA-48 }}$ like encoding genes $[76,95,97]$. More putatively, some authors suggest that $A$. baumannii may constitute an intermediate reservoir for $b l a_{\mathrm{NDM}-1}$ gene $[49,60,98]$. By the analysis of $b l a_{\mathrm{NDM}-1}$ sequence, Bonnin et al. imply that $b l a_{\mathrm{NDM}-1}$ come originally from an environmental progenitor bacteria and has been constructed in Acinetobacter by a recombination event with another resistance gene. Moreover, in A. baumannii, bla $a_{\mathrm{NDM}-1}$ gene is embedded in a transposon composite $\mathrm{Tn} 125$, which may have then 
allowed the transfer of the gene onto BHR plasmids and its secondary dissemination by HGT within Enterobacterales [60].

Autochtonous bacteria can also acquire new CEG. Environmental aquatic bacterial genera, which acquired clinical relevant CEG from contaminated water have been reported in many previous studies $[11,13,15,16,39,40,94,99]$. As autochtonous bacteria are adapted to persist in the aquatic environment, they can constitute a perennial environmental reservoir for CEG. However, the direction of the CEG transfer between human being and aquatic environment is probably not unidirectional. It could also occurs from autochtonous bacteria to human bacteria. This must then drive us to consider autochtonous bacteria like a potential "shuttle" for CEG which could ensure the transfer of the genes within aquatic and human environments.

\section{The Bacterial Shuttle Concept: When Hydric Autochtonous Bacteria Play a Role of "Genes-Mule"}

Some aquatic autochtonous bacteria are opportunistic pathogens that can cause human infection or colonization, and can transfer CEG by HGT to bacteria belonging to host microbiota (i.e., humans). These aquatic autochtonous bacteria could act as reservoirs, and more particularly, like a hub or a "bacterial shuttle" for CEG, permitting them to travel from hydric environment to the human being (and vice versa) and to persist and disseminate within humans. This is particularly true if the resistance genes transferred are clinically relevant and are located onto mobile genetic elements which facilitate their dissemination between human bacteria.

As CEG are generally carried onto transposable elements and plasmids and as HGT occurs frequently between different bacterial species belonging to Enterobacterales $[28,100]$, the example of aquatic autochtonous CPE as "bacterial shuttle" appears to be the most obvious. Supporting this idea, Potron et al. suggest a wide dissemination of an OXA-48 producing-Serratia marcescens strain in urban puddles in Marrakech. The bla $a_{\mathrm{OXA}-48}$ gene was encoded on a conjugative plasmid and was embedded in the same Tn1999 transposon that has already been isolated in K. pneumoniae strains in the country [92]. The description of a $b l a_{\mathrm{IMI}-2}$ gene flanked by transposable elements on a conjugative plasmid in a strain of E. asburiae [89] supports also this hypothesis for this bacterial species. However we chose here to focus on two bacterial genera not belonging to Enterobacterales: Aeromonas and Pseudomonas. In fact, Aeromonas and Pseudomonas are considered to be opportunistic pathogens for humans and are frequently associated with aquatic habitat and thus should be considered as good candidate to be "bacterial shuttles" and deserve special attention.

\subsection{Aeromonas Spp.}

Aeromonads belong to Gammaproteobacteria. These non-fermentative Gram-negative rods are ubiquitous and go hand-in-hand with water and aquatic environments: Frequently isolated in fresh water like rivers and lakes, drinking water, wastewater, sewage and more rarely in seawater [101]. Aeromonas spp. are opportunistic pathogens and can be associated with gastroenteritis, blood-born infections, skin and soft tissue infections. The main source for human colonization/infection is contact with contaminated water directly (e.g., recreational water, drinking water) or indirectly (e.g., animal, foodborne ... ) [101]. Some species of Aeromonas sp., including A. hydrophila are naturally resistant to carbapenems, due to the chromosomally mediated gene $c p h A$ encoding an Ambler class $\mathrm{B}$ carbapenemase [47].

Some studies report isolation of Aeromonas spp. strains carrying acquired carbapenemase encoding gene from urban aquatic environment, such as WWTP effluent, river or coastal water $[12,13,15,16,39]$. In a Japanese study, A. hydrophila and A. caviae carrying $b l a_{\mathrm{KPC}-2}$ gene on different IncP-6 plasmids were isolated from WWTP effluent and the authors suggested that the acquisition of the carbapenemase encoding gene occurred in the aquatic environment and Aeromonas may constitute an environmental reservoir for KPC-2 carbapenemase encoding genes [39]. Even if there is no clear proof that the gene transfer from clinical bacteria to Aeromonas spp. (naturally present in the aquatic environment) 
took place in the water, other studies also suggest it. A Chinese study identified of an IncP-6 plasmid encoding $b l a_{\mathrm{KPC}-2}$ gene in three $A$. taiwanensis strains isolated from sediments of an urban water. Interestingly, the $b l a_{\mathrm{KPC}-2}$ gene was inserted in a transposon $\mathrm{Tn} 3$, which had already been reported in Enterobacterales in China and in France [40]. Others studies noticed environmental Aeromonas spp. isolates carrying $b l a_{\mathrm{KPC}-2}$ gene on self-transmissible plasmids in urban water [16,42]. In the same way, Mathys et al. isolated 31 Aeromonas spp. strains producing carbapenemase from WWTP effluent, 5 carrying $b l a_{\mathrm{KPC}-2}, 4$ onto an IncP-6 plasmid [23]. A French study reported the isolation of several Aeromonas spp. strains carrying plasmidic carbapenemase encoding genes $\left(b l a_{\mathrm{NDM}}\right.$, $\left.b l a_{\mathrm{OXA}-48}, b l a_{\mathrm{VIM}}\right)$ from old biofilms formed on hospital wastewater pipelines. One of these plasmids harbouring $b l a_{\mathrm{VIM}-19}$ gene, was a conjugative plasmid [11]. In their study, Picão et al. isolated several CPB from different stages of water purification. The genetic environment of all the $b l a_{\mathrm{KPC}}$ carriers were characterized. Two different genetic environments were evidenced, a Tn4401, mostly carried by Enterobacterales commonly implicated in human pathology (Klebsiella spp., Raoultella spp., Enterobacter sp. Citrobacter spp.) and a Tn3-tnpR/ISKpn8/bla $a_{\mathrm{KPC}-2} / \mathrm{ISKpn6}$ array in Aeromonas spp. Interestingly, Aeromonas sp. is the only genus for which the two transposons has been identified [16].

The fact that autochtonous bacteria carry CEG on transferable plasmids already identified in CPE involved in human infection reinforces the idea that HGT between hydric and human bacteria can occur in aquatic environments and in humans after a waterborne infection ("bacterial shuttle" concept).

Clinical Aeromonas spp. isolates producing KPC-2, VIM, OXA-181 and GES-24 carbapenemases have already been identified in US, Israel and Japan [102-105]. A clinical case of HGT of a bla $a_{\mathrm{VIM}-1}$ gene carried by a conjugative IncA/C plasmid was established in vivo between 3 Enterobacteriaceae isolates (E. coli, K. pneumoniae and C. freundii) and an A. hydrophila isolate. Even if the route of the HGT between the four isolates could not be determined, this study proves that HGT of carbapenemase encoding gene between an aquatic bacteria (acquired after a water exposition) and more clinically relevant bacteria (probably belonging to the microbiota of the patient) is possible within a patient [106]. An HGT was suggested to occur between a human strain and an environmental strain within the intestinal tract of an hospitalized patient. In detail, this study described the transfer of a plasmid carrying $b l a_{\mathrm{TEM}-24}$ (ESBL encoding gene) from an isolate of Enterobacter aerogenes (belonging to a lineage associated with TEM-24 in French hospital) to an isolate of A. caviae [107].

\subsection{Pseudomonas Spp.}

Pseudomonas spp. are aerobic Gram-negative non-fermentative bacilli belonging to Gammaproteobacteria. Pseudomonas spp. are considered as ubiquitous bacteria and are able to colonize a wide range of habitats like soil, plants, animals and water [108]. Although, Pseudomonas aeruginosa is one of the principal agent responsible for hospital acquired infection $[109,110]$, the other species of the genus (hereinafter called Pseudomonas sp. non aeruginosa) exhibit limited pathogenicity to humans [111]. Pseudomonas AMR is mainly studied for P. aeruginosa, where acquired resistance to carbapenems could occur i) by mutation onto genes conducting to overexpression of efflux system or to overexpression of the cephalosporinase AmpC or to modification of porin protein D2 and ii) by HGT [110]. Acquisition of CEG by HGT is largely described in P. aeruginosa clinical isolates and the expansion of epidemic high-risk clones producing carbapenemase is increasing in the world [92]. Resistance by carbapenemase production in Pseudomonas non aeruginosa is less described in clinical reports. However, the carriage of CEG like $b l a_{\mathrm{KPC}-2}$ and $b l a_{\mathrm{VIM}-2}$ (carried on an class 1 integron) respectively in a clinical isolates of Pseudomonas putida and Pseudomonas fulva has been noticed [111,112].

Interestingly, a substantial number of Pseudomonas non aeruginosa isolates carrying acquired CEG were isolated from various aquatic environment. This suggests that the Pseudomonas genera may act as an environmental reservoir for the persistence and the spread of CEG in aquatic bacterial community $[11,12,15,93,94,99,113,114]$. Moreover, it is to note that Pseudomonas spp. have a propensity to form biofilm $[11,108]$ which is recognised to be a site where there is numerous exchanges of genetic material in particular by HGT [115]. 
When the genetic context of the carbapenemase encoding gene is studied, most of the studies report an association with the integron of class 1. In their study, Quinteira et al. described a Pseudomonas pseudoalcaligenes carrying a chromosomal encoded gene-bla $a_{\mathrm{VIM}-2}$ in a class 1 integron isolated from an urban sewage system [116]. As P. pseudoalcaligenes is an environmental bacteria widely distributed in aquatic habitats but rarely implicated in clinical infection, and because there was no VIM-2 producing-P. pseudoalcaligenes clinical strain isolated in the hospital during the study, the authors argued for an HGT occurrence in the aquatic environment and for a distribution of $b l a_{\mathrm{VIM}-2}$ not restricted to hospital settings [116]. Another study reported the isolation of 141 Pseudomonas spp. strains from aquatic sediments receiving communal and hospital (treated or untreated) effluents. Among these isolates, the authors noted an important proportion of the carbapenemase encoding genes $b l a_{\mathrm{VIM}-1}(20$ to $61 \%)$ and $b l a_{\mathrm{NDM}-1}(6$ to $29 \%)$ and almost one third carrying a class 1 integron; $b l a_{\mathrm{NDM}-1}$ was recovered in various Pseudomonas species including $P$. aeruginosa but more surprisingly also P. putida, P. fulva and Pseudomonas plecoglossida, which are species rarely involved in human pathology. That is why authors suggested a transfer of this gene to aquatic Pseudomonas community [117]. The same study reports the success of the transfer by in vitro conjugation to E. coli of $b l a_{\mathrm{VIM}}$ and $b l a_{\mathrm{NDM}}$ genes from P. aeruginosa and P. putida (with a higher transfer rate at 30 and $37^{\circ} \mathrm{C}$ ). This major result proved that HGT can occur between Pseudomonas spp. and Enterobacterales and that the potential role of «shuttle» between aquatic environment and human being for bacteria belonging to Pseudomonas genus appears plausible.

\section{Conclusions}

There are many reasons justifying the presence of $\mathrm{CPB}$ in aquatic environments is a great concern. The first one, and the most obvious, is that contaminated water can provide CPE to humans that can cause bacterial infections or colonization for humans. These CPE could then transfer their CEG to aquatic autochtonous bacteria that provoke the persistence and the dissemination of the CEG within aquatic ecosystem, illustrating the bacterial shuttleconcept. Moreover, aquatic autochtonous bacteria can act also as shuttle for carbapenemase encoding genes between aquatic environment and human being as it has been already suggested [88]. Humans are in contact with water in several ways and the transient implantation in the microbiota of autochtonous bacteria after a near drowning has already been noticed $[88,106]$, which strongly allows a potential transfer of genes from autochtonous bacteria to human bacteria in the gut.

Most of the available studies chose to focus onto the clinical relevant bacterial species, which produce carbapenemase excluding de facto ones that are unlikely found in human infections [23,41]. But given the fact that, autochtonous bacteria are probably a shuttle, the restricted evaluation of clinical relevant bacteria (most of the time Enterobacterales) producing carbapenemase grossly underestimates the risk for human health. In the context of the fight against AMR under the "One-Health" concept, when the emergence, the dissemination and the persistence of CEG and more generally of AMR genes is studied in the Environment, bacterial "shuttle" concept and autochtonous bacteria appear essential to be considered.

Author Contributions: F.H.-D. wrote the manuscript, developed the figure, P.L.-F. helped for writing and revised the manuscript and the figure, E.J.-B. revised the manuscript. All authors have read and agreed to the published version of the manuscript.

Funding: This research received no external funding.

Conflicts of Interest: The authors declare no conflict of interest. 


\section{References}

1. Harbarth, S.; Balkhy, H.H.; Goossens, H.; Jarlier, V.; Kluytmans, J.; Laxminarayan, R.; Saam, M.; Van Belkum, A.; Pittet, D. Antimicrobial resistance: One world, one fight! Antimicrob. Resist. Infect. Control 2015, 4, 49. [CrossRef]

2. WHO. WHO Report on Surveillance of Antibiotic Consumption. Available online: http://www.who.int/ medicines/areas/rational_use/oms-amr-amc-report-2016-2018/en/ (accessed on 23 July 2020).

3. Bush, K. Carbapenemases: Partners in crime. J. Glob. Antimicrob. Resist. 2013, 1, 7-16. [CrossRef] [PubMed]

4. Papp-Wallace, K.M.; Endimiani, A.; Taracila, M.A.; Bonomo, R.A. Carbapenems: Past, Present, and Future. Antimicrob. Agents Chemother. 2011, 55, 4943-4960. [CrossRef] [PubMed]

5. Codjoe, F.S.; Donkor, E.S. Carbapenem Resistance: A Review. Med. Sci. 2017, 6, 1. [CrossRef] [PubMed]

6. Falagas, M.; Tansarli, G.S.; Karageorgopoulos, D.E.; Vardakas, K.Z. Deaths Attributable to Carbapenem-Resistant Enterobacteriaceae Infections. Emerg. Infect. Dis. 2014, 20, 1170-1175. [CrossRef] [PubMed]

7. Stewardson, A.J.; Marimuthu, K.; Sengupta, S.; Allignol, A.; El-Bouseary, M.; Carvalho, M.J.; Hassan, B.; Delgado-Ramirez, M.A.; Arora, A.; Bagga, R.; et al. Effect of carbapenem resistance on outcomes of bloodstream infection caused by Enterobacteriaceae in low-income and middle-income countries (PANORAMA): A multinational prospective cohort study. Lancet Infect. Dis. 2019, 19, 601-610. [CrossRef]

8. Bleichenbacher, S.; Stevens, M.J.; Zurfluh, K.; Perreten, V.; Endimiani, A.; Stephan, R.; Nüesch-Inderbinen, M. Environmental dissemination of carbapenemase-producing Enterobacteriaceae in rivers in Switzerland. Environ. Pollut. 2020, 265, 115081. [CrossRef]

9. Hernando-Amado, S.; Coque, T.M.; Baquero, F.; Martínez, J.L. Defining and combating antibiotic resistance from One Health and global health perspectives. Nat. Microbiol. 2019, 4, 1432-1442. [CrossRef]

10. Almakki, A.; Jumas-Bilak, E.; Marchandin, H.; Licznar-Fajardo, P. Antibiotic resistance in urban runoff. Sci. Total Environ. 2019, 667, 64-76. [CrossRef]

11. Ory, J.; Bricheux, G.; Robin, F.; Togola, A.; Forestier, C.; Traoré, O. Biofilms in hospital effluents as a potential crossroads for carbapenemase-encoding strains. Sci. Total Environ. 2019, 657, 7-15. [CrossRef]

12. Haller, L.; Chen, H.; Ng, C.; Le, T.H.; Koh, T.H.; Barkham, T.; Sobsey, M.; Gin, K.Y.-H. Occurrence and characteristics of extended-spectrum $\beta$-lactamase- and carbapenemase-producing bacteria from hospital effluents in Singapore. Sci. Total Environ. 2018, 615, 1119-1125. [CrossRef] [PubMed]

13. De Araujo, C.F.M.; Silva, D.M.; Carneiro, M.T.; Ribeiro, S.; Fontana-Maurell, M.; Alvarez, P.; Asensi, M.D.; Zahner, V.; Carvalho-Assef, A.P.D. Detection of Carbapenemase Genes in Aquatic Environments in Rio de Janeiro, Brazil. Antimicrob. Agents Chemother. 2016, 60, 4380-4383. [CrossRef] [PubMed]

14. Zhang, X.; Lü, X.; Zong, Z. Enterobacteriaceae producing the KPC-2 carbapenemase from hospital sewage. Diagn. Microbiol. Infect. Dis. 2012, 73, 204-206. [CrossRef] [PubMed]

15. Paschoal, R.P.; Campana, E.H.; Corrêa, L.L.; Montezzi, L.F.; Barrueto, L.R.L.; Da Silva, I.R.; Bonelli, R.R.; Castro, L.D.S.; Picão, R.C. Concentration and Variety of Carbapenemase Producers in Recreational Coastal Waters Showing Distinct Levels of Pollution. Antimicrob. Agents Chemother. 2017, 61, e01963-17. [CrossRef] [PubMed]

16. Picão, R.C.; Cardoso, J.P.; Campana, E.H.; Nicoletti, A.G.; Petrolini, F.V.; Assis, D.M.; Juliano, L.; Gales, A.C. The route of antimicrobial resistance from the hospital effluent to the environment: Focus on the occurrence of KPC-producing Aeromonas spp. and Enterobacteriaceae in sewage. Diagn. Microbiol. Infect. Dis. 2013, 76, 80-85.

17. Galler, H.; Feierl, G.; Petternel, C.; Reinthaler, F.; Haas, D.; Grisold, A.J.; Luxner, J.; Zarfel, G. KPC-2 and OXA-48 carbapenemase-harbouring Enterobacteriaceae detected in an Austrian wastewater treatment plant. Clin. Microbiol. Infect. 2014, 20, O132-O134. [CrossRef] [PubMed]

18. Montezzi, L.F.; Campana, E.H.; Corrêa, L.L.; Justo, L.H.; Paschoal, R.P.; Da Silva, I.L.V.D.; Souza, M.D.C.M.; Drolshagen, M.; Picão, R.C. Occurrence of carbapenemase-producing bacteria in coastal recreational waters. Int. J. Antimicrob. Agents 2015, 45, 174-177. [CrossRef]

19. Dang, B.; Mao, D.; Xu, Y.; Luo, Y. Conjugative multi-resistant plasmids in Haihe River and their impacts on the abundance and spatial distribution of antibiotic resistance genes. Water Res. 2017, 111, 81-91. [CrossRef]

20. Mills, M.C.; Lee, J. The threat of carbapenem-resistant bacteria in the environment: Evidence of widespread contamination of reservoirs at a global scale. Environ. Pollut. 2019, 255, 113143. [CrossRef] 
21. Zhang, J.; Li, W.; Chen, J.; Qi, W.; Wang, F.; Zhou, Y. Impact of biofilm formation and detachment on the transmission of bacterial antibiotic resistance in drinking water distribution systems. Chemosphere 2018, 203, 368-380. [CrossRef]

22. Sanganyado, E.; Gwenzi, W. Antibiotic resistance in drinking water systems: Occurrence, removal, and human health risks. Sci. Total Environ. 2019, 669, 785-797. [CrossRef] [PubMed]

23. Mathys, D.A.; Mollenkopf, D.F.; Feicht, S.M.; Adams, R.J.; Albers, A.L.; Stuever, D.M.; Grooters, S.V.; Ballash, G.A.; Daniels, J.B.; Wittum, T. Carbapenemase-producing Enterobacteriaceae and Aeromonas spp. present in wastewater treatment plant effluent and nearby surface waters in the US. PLoS ONE 2019, 14, e0218650. [CrossRef]

24. Hölzel, C.S.; Tetens, J.L.; Schwaiger, K. Unraveling the Role of Vegetables in Spreading Antimicrobial-Resistant Bacteria: A Need for Quantitative Risk Assessment. Foodborne Pathog. Dis. 2018, 15, 671-688. [CrossRef] [PubMed]

25. Ambler, R.P. The structure of $\beta$-lactamases. Philos. Trans. R. Soc. B: Biol. Sci. 1980, 289, 321-331.

26. Jacoby, G.A. AmpC $\beta$-Lactamases. Clin. Microbiol. Rev. 2009, 22, 161-182. [CrossRef] [PubMed]

27. Nordmann, P.; Naas, T.; Poirel, L. Global Spread of Carbapenemase-producing Enterobacteriaceae. Emerg. Infect. Dis. 2011, 17, 1791-1798. [CrossRef] [PubMed]

28. Van Duin, D.; Doi, Y. The global epidemiology of carbapenemase-producing Enterobacteriaceae. Virulence 2016, 8, 460-469. [CrossRef]

29. Yigit, H.; Queenan, A.M.; Anderson, G.J.; Domenech-Sanchez, A.; Biddle, J.W.; Steward, C.D.; Alberti, S.; Bush, K.; Tenover, F.C. Novel Carbapenem-Hydrolyzing $\beta$-Lactamase, KPC-1, from a Carbapenem-resistant strain of Klebsiella pneumonia. Antimicrob. Agents Chemother. 2001, 45, 1151-1161. [CrossRef]

30. Oueslati, S.; Tlili, L.; Exilie, C.; Bernabeu, S.; Iorga, B.; Bonnin, R.A.; Dortet, L.; Naas, T. Different phenotypic expression of KPC $\beta$-lactamase variants and challenges in their detection. J. Antimicrob. Chemother. 2020, 75, 769-771. [CrossRef]

31. Yigit, H.; Queenan, A.M.; Anderson, G.J.; Domenech-Sanchez, A.; Biddle, J.W.; Steward, C.D.; Alberti, S.; Bush, K.; Tenover, F.C. Novel Carbapenem-Hydrolyzing $\beta$-Lactamase, KPC-1, from a Carbapenem-Resistant Strain of Klebsiella pneumoniae. Antimicrob. Agents Chemother. 2008, 52, 809. [CrossRef]

32. Nordmann, P.; Cuzon, G.; Naas, T. The real threat of Klebsiella pneumoniae carbapenemase-producing bacteria. Lancet Infect. Dis. 2009, 9, 228-236. [CrossRef]

33. Gomez, S.; Pasteran, F.G.; Faccone, D.; Tijet, N.; Rapoport, M.; Lucero, C.; Lastovetska, O.; Albornoz, E.; Galas, M.; Melano, R.G.; et al. Clonal dissemination of Klebsiella pneumoniae ST258 harbouring KPC-2 in Argentina. Clin. Microbiol. Infect. 2011, 17, 1520-1524. [CrossRef] [PubMed]

34. Baraniak, A.; Kern-Zdanowicz, I.; Filczak, K.; Łopaciuk, U.; Izdebski, R.; Herda, M.; Fiett, J.; Hryniewicz, W.; Gniadkowski, M. Emergence of Klebsiella pneumoniae ST258 with KPC-2 in Poland. Antimicrob. Agents Chemother. 2009, 53, 4565-4567. [CrossRef] [PubMed]

35. Castanheira, M.; Farrell, S.E.; Wanger, A.; Rolston, K.V.; Jones, R.N.; Mendes, R.E. Rapid expansion of KPC-2-producing Klebsiella pneumoniae isolates in two Texas hospitals due to clonal spread of ST258 and ST307 lineages. Microb. Drug Resist. 2013, 19, 295-297. [CrossRef] [PubMed]

36. Partridge, S.R.; Di Pilato, V.; Doi, Y.; Feldgarden, M.; Haft, D.H.; Klimke, W.; Kumar-Singh, S.; Liu, J.-H.; Malhotra-Kumar, S.; Prasad, A.; et al. Proposal for assignment of allele numbers for mobile colistin resistance (mcr) genes. J. Antimicrob. Chemother. 2018, 73, 2625-2630. [CrossRef]

37. Cuzon, G.; Naas, T.; Nordmann, P. Functional Characterization of Tn4401, a Tn3-Based Transposon Involved inblaKPCGene Mobilization. Antimicrob. Agents Chemother. 2011, 55, 5370-5373. [CrossRef]

38. Naas, T.; Cuzon, G.; Villegas, M.-V.; Lartigue, M.-F.; Quinn, J.P.; Nordmann, P. Genetic Structures at the Origin of Acquisition of the $\beta$-Lactamase blaKPC Gene. Antimicrob. Agents Chemother. 2008, 52, 1257-1263. [CrossRef]

39. Sekizuka, T.; Inamine, Y.; Segawa, T.; Hashino, M.; Yatsu, K.; Kuroda, M. Potential KPC-2 carbapenemase reservoir of environmental Aeromonas hydrophila and Aeromonas caviae isolates from the effluent of an urban wastewater treatment plant in Japan. Environ. Microbiol. Rep. 2019, 11, 589-597. [CrossRef]

40. Hu, X.; Yu, X.; Shang, Y.; Xu, H.; Guo, L.; Liang, Y.; Kang, Y.; Song, L.; Sun, J.; Yue, F.; et al. Emergence and Characterization of a Novel IncP-6 Plasmid Harboring blaKPC-2 and qnrS2 Genes in Aeromonas taiwanensis Isolates. Front. Microbiol. 2019, 10, 2132. [CrossRef] 
41. Nascimento, T.; Cantamessa, R.; Melo, L.; Fernandes, M.R.; Fraga, E.; Dropa, M.; Sato, M.I.Z.; Cerdeira, L.; Lincop, N. International high-risk clones of Klebsiella pneumoniae KPC-2/CC258 and Escherichia coli CTX-M-15/CC10 in urban lake waters. Sci. Total Environ. 2017, 598, 910-915. [CrossRef]

42. Xu, H.; Wang, X.; Yu, X.; Zhang, J.; Guo, L.; Huang, C.; Jiang, X.; Li, X.; Feng, Y.; Zheng, B. First detection and genomics analysis of KPC-2-producing Citrobacter isolates from river sediments. Environ. Pollut. 2018, 235, 931-937. [CrossRef] [PubMed]

43. Queenan, A.M.; Bush, K. Carbapenemases: The Versatile $\beta$-Lactamases. Clin. Microbiol. Rev. 2007, 20, 440-458. [CrossRef] [PubMed]

44. Livermore, D.M.; Woodford, N. Carbapenemases: A problem in waiting? Curr. Opin. Microbiol. 2000, 3, 489-495. [CrossRef]

45. Saino, Y.; Kobayashi, F.; Inoue, M.; Mitsuhashi, S. Purification and properties of inducible penicillin beta-lactamase isolated from Pseudomonas maltophilia. Antimicrob. Agents Chemother. 1982, 22, 564-570. [CrossRef] [PubMed]

46. Lim, H.M.; Pène, J.J.; Shaw, R.W. Cloning, nucleotide sequence, and expression of the Bacillus cereus 5/B/6 beta-lactamase II structural gene. J. Bacteriol. 1988, 170, 2873-2878. [CrossRef] [PubMed]

47. Segatore, B.; Massidda, O.; Satta, G.; Setacci, D.; Amicosante, G. High specificity of cphA-encoded metallo-beta-lactamase from Aeromonas hydrophila AE036 for carbapenems and its contribution to beta-lactam resistance. Antimicrob. Agents Chemother. 1993, 37, 1324-1328. [CrossRef] [PubMed]

48. Yong, D.; Toleman, M.A.; Giske, C.G.; Cho, H.S.; Sundman, K.; Lee, K.; Walsh, T.R. Characterization of a New Metallo- $\beta$-Lactamase Gene, blaNDM-1, and a Novel Erythromycin Esterase Gene Carried on a Unique Genetic Structure in Klebsiella pneumoniae Sequence Type 14 from India. Antimicrob. Agents Chemother. 2009, 53, 5046-5054. [CrossRef]

49. Bontron, S.; Nordmann, P.; Poirel, L. Transposition of Tn125encoding the NDM-1 carbapenemase in Acinetobacter baumannii. Antimicrob. Agents Chemother. 2016, 60, 7245-7251.

50. Rolain, J.; Parola, P.; Cornaglia, G. New Delhi metallo-beta-lactamase (NDM-1): Towards a new pandemia? Clin. Microbiol. Infect. 2010, 16, 1699-1701. [CrossRef]

51. Kumarasamy, K.K.; Toleman, M.A.; Walsh, T.R.; Bagaria, J.; Butt, F.; Balakrishnan, R.; Chaudhary, U.; Doumith, M.; Giske, C.G.; Irfan, S.; et al. Emergence of a new antibiotic resistance mechanism in India, Pakistan, and the UK: A molecular, biological, and epidemiological study. Lancet Infect. Dis. 2010, 10, 597-602. [CrossRef]

52. Khan, N.H.; Ishii, Y.; Kimata-Kino, N.; Esaki, H.; Nishino, T.; Nishimura, M.; Kogure, K. Isolation of Pseudomonas aeruginosa from Open Ocean and Comparison with Freshwater, Clinical, and Animal Isolates. Microb. Ecol. 2007, 53, 173-186. [CrossRef] [PubMed]

53. Basu, S. Variants of the New Delhi metallo- $\beta$-lactamase: New kids on the block. Futur. Microbiol. 2020, 15, 465-467. [CrossRef] [PubMed]

54. Datta, S.; Mitra, S.; Chattopadhyay, P.; Som, T.; Mukherjee, S.; Basu, S. Spread and exchange of bla NDM-1 in hospitalized neonates: Role of mobilizable genetic elements. Eur. J. Clin. Microbiol. Infect. Dis. 2016, 36, 255-265. [CrossRef] [PubMed]

55. Poirel, L.; Dortet, L.; Bernabeu, S.; Nordmann, P. Genetic Features of blaNDM-1-Positive Enterobacteriaceae. Antimicrob. Agents Chemother. 2011, 55, 5403-5407. [CrossRef] [PubMed]

56. Khan, A.U.; Maryam, L.; Zarrilli, R. Structure, Genetics and Worldwide Spread of New Delhi Metallo- $\beta$-lactamase (NDM): A threat to public health. BMC Microbiol. 2017, 17, 101. [CrossRef] [PubMed]

57. An, J.; Guo, L.; Zhou, L.; Ma, Y.; Luo, Y.; Tao, C.; Yang, J. NDM-producing Enterobacteriaceae in a Chinese hospital, 2014-2015: Identification of NDM-producing Citrobacter werkmanii and acquisition of bla NDM-1-carrying plasmid in vivo in a clinical Escherichia coli isolate. J. Med. Microbiol. 2016, 65, 1253-1259. [CrossRef]

58. Zhang, F.; Xie, L.; Wang, X.; Han, L.; Guo, X.; Ni, Y.; Qu, H.; Sun, J. Further Spread of blaNDM-5 in Enterobacteriaceae via IncX3 Plasmids in Shanghai, China. Front. Microbiol. 2016, 7, 424. [CrossRef]

59. Janvier, F.; Jeannot, K.; Tessé, S.; Robert-Nicoud, M.; Delacour, H.; Rapp, C.; Mérens, A. Molecular characterization of blaNDM-1 in a Sequence Type 235 Pseudomonas aeruginosa isolate from France. Antimicrob. Agents Chemother. 2013, 57, 3408-3411. [CrossRef]

60. Bonnin, R.A.; Poirel, L.; Nordmann, P. New Delhi metallo- $\beta$-lactamase-producing Acinetobacter baumannii: A novel paradigm for spreading antibiotic resistance genes. Futur. Microbiol. 2014, 9, 33-41. [CrossRef] 
61. Partridge, S.R.; Iredell, J.R. Genetic Contexts ofblaNDM-1. Antimicrob. Agents Chemother. 2012, 56, 6065-6067. [CrossRef]

62. Toleman, M.A.; Spencer, J.; Jones, L.; Walsh, T.R. blaNDM-1Is a Chimera Likely Constructed in Acinetobacter baumannii. Antimicrob. Agents Chemother. 2012, 56, 2773-2776. [CrossRef] [PubMed]

63. Almakki, A.; Maure, A.; Pantel, A.; Romano-Bertrand, S.; Masnou, A.; Marchandin, H.; Jumas-Bilak, E.; Licznar-Fajardo, P. NDM-5-producing Escherichia coli in an urban river in Montpellier, France. Int. J. Antimicrob. Agents 2017, 50, 123-124. [CrossRef] [PubMed]

64. Walther-Rasmussen, J.; Høiby, N. Class A carbapenemases. J. Antimicrob. Chemother. 2007, 60, 470-482. [CrossRef] [PubMed]

65. Zhanel, G.G.; Lawson, C.D.; Adam, H.; Schweizer, F.; Zelenitsky, S.; Lagacé-Wiens, P.R.S.; Denisuik, A.; Rubinstein, E.; Gin, A.S.; Hoban, D.J.; et al. Ceftazidime-Avibactam: A Novel Cephalosporin/ $\beta$-lactamase Inhibitor Combination. Drugs 2013, 73, 159-177. [CrossRef] [PubMed]

66. Poirel, L.; Héritier, C.; Tolün, V.; Nordmann, P. Emergence of Oxacillinase-Mediated Resistance to Imipenem in Klebsiella pneumoniae. Antimicrob. Agents Chemother. 2004, 48, 15-22. [CrossRef]

67. Paton, R.; Miles, R.; Hood, J.; Amyes, S. ARI 1: $\beta$-lactamase-mediated imipenem resistance in Acinetobacter baumannii. Int. J. Antimicrob. Agents 1993, 2, 81-87. [CrossRef]

68. Héritier, C.; Poirel, L.; Aubert, D.; Nordmann, P. Genetic and Functional Analysis of the Chromosome-Encoded Carbapenem-Hydrolyzing Oxacillinase OXA-40 of Acinetobacter baumannii. Antimicrob. Agents Chemother. 2003, 47, 268-273. [CrossRef]

69. Pitout, J.D.; Peirano, G.; Kock, M.M.; Strydom, K.-A.; Matsumura, Y. The Global Ascendency of OXA-48-Type Carbapenemases. Clin. Microbiol. Rev. 2019, 33. [CrossRef]

70. Poirel, L.; Potron, A.; Nordmann, P. OXA-48-like carbapenemases: The phantom menace. J. Antimicrob. Chemother. 2012, 67, 1597-1606. [CrossRef]

71. Poirel, L.; Bonnin, R.A.; Nordmann, P. Genetic Features of the Widespread Plasmid Coding for the Carbapenemase OXA-48. Antimicrob. Agents Chemother. 2011, 56, 559-562. [CrossRef]

72. Carattoli, A. Resistance Plasmid Families in Enterobacteriaceae. Antimicrob. Agents Chemother. 2009, 53, 2227-2238. [CrossRef] [PubMed]

73. Carrër, A.; Poirel, L.; Yilmaz, M.; Akan, O.A.; Feriha, C.; Cuzon, G.; Matar, G.; Honderlick, P.; Nordmann, P. Spread of OXA-48-Encoding Plasmid in Turkey and Beyond. Antimicrob. Agents Chemother. 2010, 54, 1369-1373. [CrossRef] [PubMed]

74. Skalova, A.; Chudejova, K.; Rotova, V.; Medvecky, M.; Studentova, V.; Chudackova, E.; Lavicka, P.; Bergerova, T.; Jakubu, V.; Zemlickova, H.; et al. Molecular Characterization of OXA-48-Like-Producing Enterobacteriaceae in the Czech Republic and Evidence for Horizontal Transfer of pOXA-48-Like Plasmids. Antimicrob. Agents Chemother. 2016, 61. [CrossRef]

75. Mairi, A.; Pantel, A.; Sotto, A.; Lavigne, J.-P.; Touati, A. OXA-48-like carbapenemases producing Enterobacteriaceae in different niches. Eur. J. Clin. Microbiol. Infect. Dis. 2017, 37, 587-604. [CrossRef] [PubMed]

76. Potron, A.; Poirel, L.; Bussy, F.; Nordmann, P. Occurrence of the Carbapenem-Hydrolyzing $\beta$-Lactamase GeneblaOXA-48in the Environment in Morocco. Antimicrob. Agents Chemother. 2011, 55, 5413-5414. [CrossRef]

77. Tanner, W.D.; Vanderslice, J.A.; Goel, R.K.; Leecaster, M.K.; Fisher, M.A.; Olstadt, J.; Gurley, C.M.; Morris, A.G.; Seely, K.A.; Chapman, L.; et al. Multi-state study of Enterobacteriaceae harboring extended-spectrum beta-lactamase and carbapenemase genes in U.S. drinking water. Sci. Rep. 2019, 9, 3938. [CrossRef]

78. Aubron, C.; Poirel, L.; Ash, R.J.; Nordmann, P. Carbapenemase-producing Enterobacteriaceae, U.S. Rivers. Emerg. Infect. Dis. 2005, 11, 260-264. [CrossRef]

79. Muraleedharan, C.; Talreja, D.; Kanwar, M.; Kumar, A.; Walia, S.K. Occurrence of extended-spectrum $\beta$-lactamase-producing bacteria in urban Clinton River habitat. J. Glob. Antimicrob. Resist. 2019, 16, 225-235. [CrossRef]

80. Poirel, L.; Barbosa-Vasconcelos, A.; Simões, R.R.; Costa, P.M.; Liu, W.; Nordmann, P. Environmental KPC-Producing Escherichia coli Isolates in Portugal. Antimicrob. Agents Chemother. 2011, 56, 1662-1663. [CrossRef]

81. Chouchani, C.; Marrakchi, R.; Henriques, I.; Correia, A. Occurrence of IMP-8, IMP-10, and IMP-13 metallo- $\beta$-lactamases located on class 1 integrons and other extended-spectrum $\beta$-lactamases in bacterial isolates from Tunisian rivers. Scand. J. Infect. Dis. 2012, 45, 95-103. [CrossRef] 
82. Oliveira, S.; Moura, R.A.; Silva, K.C.; Pavez, M.; McCulloch, J.A.; Dropa, M.; Matté, M.H.; Mamizuka, E.M.; Sato, M.I.Z.; De Castro, A.F.P.; et al. Isolation of KPC-2-producing Klebsiella pneumoniae strains belonging to the high-risk multiresistant clonal complex 11 (ST437 and ST340) in urban rivers. J. Antimicrob. Chemother. 2013, 69, 849-852. [CrossRef] [PubMed]

83. Tafoukt, R.; Touati, A.; Leangapichart, T.; Bakour, S.; Rolain, J.-M. Characterization of OXA-48-like-producing Enterobacteriaceae isolated from river water in Algeria. Water Res. 2017, 120, 185-189. [CrossRef]

84. Petrovich, M.L.; Zilberman, A.; Kaplan, A.; Eliraz, G.R.; Wang, Y.; Langenfeld, K.; Duhaime, M.; Wigginton, K.; Poretsky, R.; Avisar, D.; et al. Microbial and Viral Communities and Their Antibiotic Resistance Genes Throughout a Hospital Wastewater Treatment System. Front. Microbiol. 2020, 11, 153. [CrossRef] [PubMed]

85. Chagas, T.P.G.; Seki, L.; Da Silva, D.; Asensi, M. Occurrence of KPC-2-producing Klebsiella pneumoniae strains in hospital wastewater. J. Hosp. Infect. 2011, 77, 281. [CrossRef] [PubMed]

86. Davin-Regli, A.; Lavigne, J.-P.; Pagès, J.-M. Enterobacter spp.: Update on Taxonomy, Clinical Aspects, and Emerging Antimicrobial Resistance. Clin. Microbiol. Rev. 2019, 32. [CrossRef] [PubMed]

87. Grimont, F.; Grimont, P.A.D. The Genus Enterobacter. Prokaryote 2006, 6, 197-214.

88. Laurens, C.; Jean-Pierre, H.; Licznar-Fajardo, P.; Hantova, S.; Godreuil, S.; Martinez, O.; Jumas-Bilak, E. Transmission of IMI-2 carbapenemase-producing Enterobacteriaceae from river water to human. J. Glob. Antimicrob. Resist. 2018, 15, 88-92. [CrossRef] [PubMed]

89. Rotova, V.; Papagiannitsis, C.C.; Chudejova, K.; Medvecky, M.; Skalova, A.; Adámková, V.; Hrabák, J. First description of the emergence of Enterobacter asburiae producing IMI-2 carbapenemase in the Czech Republic. J. Glob. Antimicrob. Resist. 2017, 11, 98-99. [CrossRef]

90. Harmon, D.E.; Miranda, O.; McCarley, A.; Eshaghian, M.; Carlson, N.; Ruiz, C. Prevalence and characterization of carbapenem-resistant bacteria in water bodies in the Los Angeles-Southern California area. Microbiologyopen 2018, 8, e00692. [CrossRef]

91. Falgenhauer, L.; Schwengers, O.; Schmiedel, J.; Baars, C.; Lambrecht, O.; Heß, S.; Berendonk, T.U.; Falgenhauer, J.; Chakraborty, T.; Imirzalioglu, C. Multidrug-resitant and clinically relevant Gram-negative bacteria are present in German surface waters. Front. Microbiol. 2019, 10, 2779. [CrossRef]

92. Potron, A.; Poirel, L.; Nordmann, P. Emerging broad-spectrum resistance in Pseudomonas aeruginosa and Acinetobacter baumannii: Mechanisms and epidemiology. Int. J. Antimicrob. Agents 2015, 45, 568-585. [CrossRef] [PubMed]

93. Girlich, D.; Poirel, L.; Nordmann, P. Novel ambler class A carbapenem-hydrolyzing beta-lactamase from a Pseudomonas fluorescens isolate from the Seine river, Paris, France. Antimicrob. Agents Chemother. 2010, 54, 328-332. [CrossRef] [PubMed]

94. Xin, R.; Zhang, K.; Wu, N.; Zhang, Y.; Niu, Z. The pollution level of the blaOXA-58 carbapenemase gene in coastal water and its host bacteria characteristics. Environ. Pollut. 2019, 244, 66-71. [CrossRef] [PubMed]

95. Tacão, M.; Correia, A.; Henriques, I. Environmental Shewanella xiamenensis strains that carry blaOXA-48 or blaOXA-204 genes: Additional proof for blaOXA-48-Like gene origin. Antimicrob. Agents Chemother. 2013, 57, 6399-6400. [CrossRef] [PubMed]

96. Wolff, M.; Joly-Guillou, M.-L.; Pajot, O. Le point sur les carabapénèmes. Réanimation 2008, 17, 242-250. [CrossRef]

97. Poirel, L.; Héritier, C.; Nordmann, P. Chromosome-Encoded Ambler Class D $\beta$-Lactamase of Shewanella oneidensis as a Progenitor of Carbapenem-Hydrolyzing Oxacillinase. Antimicrob. Agents Chemother. 2004, 48, 348-351. [CrossRef]

98. Nordmann, P.; Dortet, L.; Poirel, L. Carbapenem resistance in Enterobacteriaceae: Here is the storm! Trends Mol. Med. 2012, 18, 263-272. [CrossRef]

99. Tacão, M.; Correia, A.; Henriques, I. Low Prevalence of Carbapenem-Resistant Bacteria in River Water: Resistance Is Mostly Related to Intrinsic Mechanisms. Microb. Drug Resist. 2015, 21, 497-506. [CrossRef]

100. Baranovsky, S.; Jumas-Bilak, E.; Lotthé, A.; Marchandin, H.; Parer, S.; Hicheri, Y.; Romano-Bertrand, S. Tracking the spread routes of opportunistic premise plumbing pathogens in a haematology unit with water points-of-use protected by antimicrobial filters. J. Hosp. Infect. 2018, 98, 53-59. [CrossRef]

101. Janda, J.M.; Abbott, S.L. The Genus Aeromonas: Taxonomy, Pathogenicity, and Infection. Clin. Microbiol. Rev. 2010, 23, 35-73. [CrossRef] 
102. Hughes, H.Y.; Conlan, S.; Lau, A.F.; Dekker, J.P.; Michelin, A.V.; Youn, J.-H.; Henderson, D.K.; Frank, K.M.; Segre, J.A.; Palmore, T.N. Detection and Whole-Genome Sequencing of Carbapenemase-Producing Aeromonas hydrophila Isolates from Routine Perirectal Surveillance Culture. J. Clin. Microbiol. 2016, 54, 1167-1170. [CrossRef]

103. Anandan, S.; Gopi, R.; Kumar, D.R.N.; Sethuvel, D.P.M.; Gunasekaran, P.; Walia, K.; Veeraraghavan, B. First report of bla OXA-181 -mediated carbapenem resistance in Aeromonas caviae in association with pKP3-A: Threat for rapid dissemination. J. Glob. Antimicrob. Resist. 2017, 10, 310-314. [CrossRef] [PubMed]

104. Uechi, K.; Tada, T.; Sawachi, Y.; Hishinuma, T.; Takaesu, R.; Nakama, M.; Nakasone, I.; Kirikae, T.; Fujita, J. A carbapenem-resistant clinical isolate of Aeromonas hydrophila in Japan harbouring an acquired gene encoding GES-24 ß-lactamase. J. Med. Microbiol. 2018, 67, 1535-1537. [CrossRef] [PubMed]

105. Adler, A.; Assous, M.V.; Paikin, S.; Shulman, A.; Miller-Roll, T.; Hillel, S.; Aronov, R.; Carmeli, Y.; Schwaber, M.J. Emergence of VIM-producing Aeromonas caviae in Israeli hospitals. J. Antimicrob. Chemother. 2014, 69, 1211-1214. [CrossRef]

106. Bosch, T.; Schade, R.; Landman, F.; Schouls, L.; Van Dijk, K. A blaVIM-1 positive Aeromonas hydrophila strain in a near-drowning patient: Evidence for interspecies plasmid transfer within the patient. Future Microbiol. 2019, 14, 1191-1197. [CrossRef] [PubMed]

107. Marchandin, H.; Jumas-Bilak, E.; Chanal, C.; Godreuil, S.; Darbas, H.; Jean-Pierre, H.; Bonnet, R. Extended-Spectrum $\beta$-Lactamase TEM-24 in an Aeromonas Clinical Strain: Acquisition from the Prevalent Enterobacter aerogenes Clone in France. Antimicrob. Agents Chemother. 2003, 47, 3994-3995. [CrossRef]

108. Silby, M.W.; Winstanley, C.; Godfrey, S.A.C.; Levy, S.B.; Jackson, R.W. Pseudomonas genomes: Diverse and adaptable. FEMS Microbiol. Rev. 2011, 35, 652-680. [CrossRef]

109. Vincent, J.-L.; Rello, J.; Marshall, J.; Silva, E.; Anzueto, A.; Martin, C.; Moreno, R.; Lipman, J.; Gomersall, C.; Sakr, Y.; et al. International Study of the Prevalence and Outcomes of Infection in Intensive Care Units. JAMA 2009, 302, 2323-2329. [CrossRef]

110. Oliver, A.; Mulet, X.; López-Causapé, C.; Juan, C. The increasing threat of Pseudomonas aeruginosa high-risk clones. Drug Resist. Updat. 2015, 21-22, 41-59. [CrossRef]

111. Chamon, R.C.; Da Rocha, J.A.; Martins, I.A.; Pires, L.L.; De Almeida, B.M.; Leite, N.S.; Souza, C.R.V.D.M.; Zahner, V.; Ribeiro, R.L.; Chagas, T.P.G.; et al. KPC-2 producing Pseudomonas putida as an unexpected pathogen of catheter-associated bloodstream infection. J. Infect. Dev. Ctries. 2020, 14, 411-414. [CrossRef]

112. Almuzara, M.N.; Vazquez, M.; Tanaka, N.; Turco, M.; Ramirez, M.S.; Lopez, E.L.; Pasteran, F.; Rapoport, M.; Procopio, A.; Vay, C.A. First Case of Human Infection Due to Pseudomonas fulva, an Environmental Bacterium Isolated from Cerebrospinal Fluid. J. Clin. Microbiol. 2009, 48, 660-664. [CrossRef] [PubMed]

113. Romero, J.L.; Burgos, M.J.G.; Pérez-Pulido, R.; Gálvez, A.; Lucas, R. Resistance to Antibiotics, Biocides, Preservatives and Metals in Bacteria Isolated from Seafoods: Co-Selection of Strains Resistant or Tolerant to Different Classes of Compounds. Front. Microbiol. 2017, 8, 1650. [CrossRef]

114. Isozumi, R.; Yoshimatsu, K.; Yamashiro, T.; Hasebe, F.; Nguyen, B.M.; Ngo, T.C.; Yasuda, S.P.; Koma, T.; Shimizu, K.; Arikawa, J. blaNDM-1-positive Klebsiella pneumoniae from Environment, Vietnam. Emerg. Infect. Dis. 2012, 18, 1383-1385. [CrossRef] [PubMed]

115. Filloux, A.; Vallet-Gely, I. Biofilm: Mise en place et organisation d'une communauté bactérienne. Médecine/Sciences 2003, 19,77-83. [CrossRef] [PubMed]

116. Quinteira, S.; Ferreira, H.N.; Peixe, L. First Isolation of blaVIM-2 in an Environmental Isolate of Pseudomonas pseudoalcaligenes. Antimicrob. Agents Chemother. 2005, 49, 2140-2141. [CrossRef] [PubMed]

117. Devarajan, N.; Köhler, T.; Sivalingam, P.; Van Delden, C.; Mulaji, C.K.; Mpiana, P.T.; Ibelings, B.W.; Poté, J. Antibiotic resistant Pseudomonas spp. in the aquatic environment: A prevalence study under tropical and temperate climate conditions. Water Res. 2017, 115, 256-265. [CrossRef]

Publisher's Note: MDPI stays neutral with regard to jurisdictional claims in published maps and institutional affiliations. 